$\xi=-1$

\title{
Consumer Protection Regulations in Life Insurance industry and its challenges: An empirical analysis from Indonesia
}

\author{
Agustinus Nicholas L Tobing \\ Universitas Pelita Harapan - Executive Education Centre \\ *Corresponding author E-mail: Augie.nicholas@gmail.com
}

\begin{abstract}
Trust is a crucial factor in the financial industry. Some financial scandals that had impacted Indonesia include the economic crisis in 1998 and have encouraged the regulator to apply adequate consumer protection for the people of Indonesia. In addition, the existence of adequate consumer protection will have a direct impact on the Indonesian financial industry, especially the life insurance sector where the penetration rate is still low in the last 10 years. In the Indonesian context, the implementation of consumer protection is immature and inconsistent. Based on empirical research, this paper explored the existing conditions of consumer protection implementation across life insurance industry in Indonesia. Moreover, this paper also analyzed the perception of the benefits and the challenges in implementing such requirements. The study found that consumer protection is still at the work in progress stage, inconsistent and not optimally implemented although there are number of benefits and risks if it were implemented as required. This condition has arisen due to the lack of regulator's commitment in the consistent implementation, lack of assurance on the quality, improper selling process, as well as limitations in capability and competence in the appointed dispute resolution body. This study suggests a number of actions: [1] Periodic regulator quality assurance for the quality of implementation in the form of assurance review and sanctions impose; [2] strengthening the need based selling for life insurance companies; [3] developing an effective and measurable financial literacy and financial inclusion programs for consumers; [4] building a life insurance product and process related competency and capability of the arbitrator and mediator from the appointed dispute resolution; and [5] establishing awareness and the existence of the dispute resolution body across cities in Indonesia.
\end{abstract}

Keywords: Consumer Protection, Life Insurance, Regulation, Disclosure.

\section{Introduction}

The development of the insurance industry in Indonesia is quite positive. The Indonesian Financial Service Authority ("Otoritas Jasa Keuangan, OJK") noted that there has been significant growth in the last five years since 2012 in term of assets size. OJK is an independent and integrated financial authority that established by the Law (1). It has authority to regulate, supervise, inspect, and investigate all financial activities and institutions in Indonesia. It is mandated to implement and integrated regulation and supervision towards all financial services activities, including insurance. Based on data from OJK, the total assets of the insurance industry reached IDR 584.02 trillion in 2012, while by the end of 2016, its assets jumped to IDR 968.92 trillion (2). The penetration and insurance density are also higher. Insurance penetration describes the development of insurance when compared with the development of Gross Domestic Product ("GDP"). While the density describes the average expenditure of Indonesian population for insurance within a year. As of January 2017, the insurance industry penetration reached 2.87 percent of GDP. While the density, the average spending of Indonesian population for insurance amounted to IDR 1.29 million per year. However, this penetration is still lower than regional countries such as Singapore, Malaysia, and Thailand where the rate have reached 5 percent (2). As of February 2017, the total number of insurance companies in Indonesia reached 138 companies which consists of general insurance
[76 companies), life insurance [52 companies), reinsurance [5 companies), compulsory insurance [3 companies) and social insurance [2 companies).

Specifically, life insurance industry is important as it helps transfer risks away from the insured to the policy issuer. By helping to transfer risks, insurance enables the insured to undertake projects or engage in economic activities and transactions that they would otherwise have not been engaged due to the risk involved. Further, insurance manages risk by pooling exposures such that aggregate losses are ultimately shared across the economy. This applies more so for long term insurance as life policy issuers remain one of the major investors with funds being invested in the real economy mainly in the form of debt and equity instruments. Due to its long-term nature and the significant contribution to the economy (3), life insurance is at the fore when it comes to the right of adequate consumer protection such as demanding disclosure of accurate and reliable information at the time of deciding to buy or sell insurance. Due to its significant contribution to financial assets, the consumer protection aspect is deemed as important by both the policy issuer and insured (refer Figure 1). According to the Financial Services Authority Report in July 2017, with nearly IDR 488.86 trillion, life policy issuers hold almost four times the financial assets of non-life policy issuers (4). As shown by Figure 1, there was a small contribution by Sharia Insurance in the life insurance companies' asset size. Sharia insurance is a system where the participants share the risks by donating (infaq) part or the entire contribution through the tabarru' that will be used to pay 
the claim, in case an accident occurs to one or some of the participants. The company's role in this case is only as the fiduciary company to manage and invest the tabarru' collected from participants' contribution. For many families, a life insurance policy is necessary for financial continuity in the event of an unexpected death. The policyholder in seeking to buy an insurance policy is usually is expected to disclose all information necessary that will enable an intermediary to provide relevant advice. In the same vein, policy issuer is also expected to conduct a proper selling process based on the consumer's needs which also covers the sufficient explanation about products, features, fees, benefits, exclusions and illustrations that are relevant to the insurance policy.

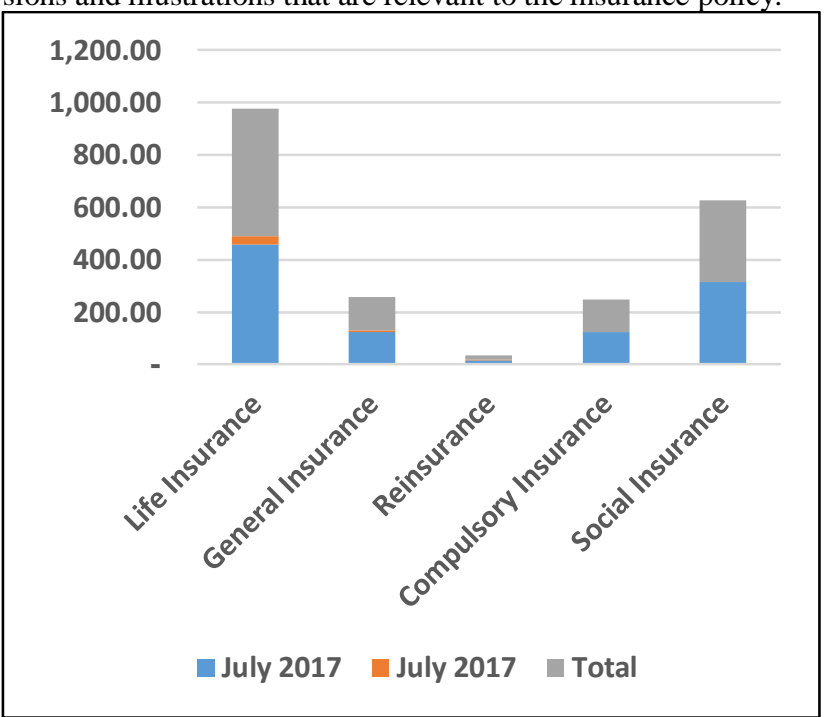

Figure 1 - Insurance Industry by Asset Size (in trillions IDR) Source: OJK Statistics Data as of July 2017

As Indonesia is an attractive market for life insurance industry and as there are still opportunities to improve the industry penetration and the density, the regulator (OJK) prioritized the consumer protection (5) as one of its main oversight responsibility. This is in accordance to Article 31 of Law No. 21 of 2011 on the Financial Services Authority that states the OJK will issue further provisions on consumer protection in the financial services sector (3). The OJK issued a Consumer Protection Act for financial industry in (6) which emphasized the transparency of products, a proper need based selling process, consumer complaint reporting and mechanism.

This paper will explore the implementation of consumer protection regulation in the life insurance industry and will highlight the critical review over its implementation based on the facts gathered as well as the insight from the consumer protection related employees in the life insurance companies such as compliance officer, consumer services, management and legal officer.

Taking account of this situation, this paper tries to answer a number of questions. Firstly, what are the existing condition of consumer protection implementation in Indonesia? Secondly, how can an adequate consumer protection provide benefits as well as mitigate risks when it is well implemented? Furthermore, what are the challenges of consumer protection implementation in Indonesia?

\section{Literature Review}

\subsection{Regulatory Requirements of OJK Regulation on Consumer Protection}

The OJK has finally issued (6) on Consumer Protection in the Financial Services Sector ("Regulation"). The protective measures are realized by establishing several obligations on financial service providers including the creation of an internal disputes resolution unit and mechanisms for the resolution of consumer disputes.
The Regulation is relevant to parties acting as financial service providers covering commercial banks, rural banks, parties involved in the capital market (e.g. investment managers, stock brokers, custodian banks), investment consultants, insurance and reinsurance companies, financing companies, pawnshops, pension funds, saving and debt assurance companies (collectively referred as "Financial Service Providers").

The Regulation is also relevant to consumers of financial services defined as persons who place funds or utilize the services of a Financial Service Provider including insurance policy holders, investors, and pension fund participants.

The Regulation establishes several requirements related to the provision of services by Financial Service Providers including: 1] information disclosure; 2] consumer education; 3] access to financial services; 4] marketing conduct; 5] standardized contracts; 6] prevention of conflicts of interest; and 7] dispute resolution.

In term of information disclosure, the Financial Service Providers must provide their consumers with accurate information with respect to [1] the products and services offered; [2] Acceptance, suspension or refusal of an application for financial products or services; [3] all fees and charges related to a financial product or service; and [4] changes to benefits, costs, risks, or terms and conditions of a financial product or service.

The insurance consumer would have comprehensive information of the insurance product prior of deciding to buy the insurance policy while the policy issuer would expect the insurance consumers to provide and to disclose the information as much as possible in order to be able to advise or to recommend the right product based on the consumer needs and the consumer risk profile.

In term of consumer education, the Financial Service Providers must provide a financial literacy initiatives including the requirement to submit the financial literacy plan and its realizations to OJK on bi-yearly basis. This is in line with the objectives from the regulator to improve the penetration rate in insurance industry.

In term of access to financial services, the Financial Service Providers must provide a financial inclusion program to its consumers. This is including the requirement to submit the financial inclusion plan and its realizations to OJK on bi-yearly basis. This is also in line with the objectives from the regulator to improve the penetration rate in insurance industry.

In terms of marketing conduct, the Financial Service Providers must comply with the requirements of product information to consumers, languages in advertising, historical performances, research data, and criteria of information in the company's website.

For standardized contracts, the Financial Service Providers must develop and comply with the mandatory provisions in the life insurance contract such as exclusions, terms and conditions, and disputes.

And finally, in term of the dispute resolution, the Financial Service Providers must provide the right to the consumers to settle the disputes through the mandatory mechanism by internally or externally using the appointed dispute resolution body. In addition, the regulation also specifically states the expectation of the turnaround time (TAT) for handling consumer complaint within 20 working days as well as the set of procedures required to provide a regulatory report and reconciliation to regulator on the complaint matters in quarterly basis.

To sum up, the benefits of the consumer protection (7), it promotes efficiency, transparency and deepening of retail financial markets. Consumer protection would improve governance of financial institutions as well as would help build demand for good governance of the sector.

\section{Disclosure of Information}

Disclosures ensure both parties are aware of potential consequences of their agreement and the actions arising thereof. This is because an insurance policy is a contractual obligation and may contain aspects that one party and mostly the buyer may not under- 
stand yet there are many disclosures involved. Since adequate disclosure is important in an insurance contract and defines the relationship between policy issuer and the insured, it is important that one understands provisions therein and provides correct information. As widely known in the insurance world, there are 7 insurance principles; (a) utmost good faith (b) insurable interest (c) indemnity (d) contribution (e) subrogation (f) loss minimization and $(\mathrm{g})$ nearest cause. To provide an adequate disclosure is in line with one of the fundamental insurance principles so called principle of good faith or "utmost the good faith". To protect the interest, (8) regulates that: "Any false or incorrect information, nor any notify the things known to the insured, how good faith is to him. That is so, that if the policy issuer had known the true situation, the treaty would not be closed, or not covered under the same conditions, resulting in the cancellation of the coverage " (KUHD). Thus, the policy issuer as a 'seller' policy should be protected against the possibility of misinformation provided by the applicant or insured about the object of coverage, so if the policy issuer knows he will not accept the coverage or accept it but with different conditions. Violation of this good faith principle may result in the coverage being null and void from the beginning and or repairing under different conditions. Applying for life insurance requires the disclosure of multiple aspects of an insured's personal history. For policy issuer to properly assess the financial risk posed by the insured, information that would otherwise be considered private and confidential must be revealed in order for proper and accurate analysis to be conducted. This information may include medical history, family history, criminal history and driving history.

\subsection{Disclosure of Information requirement under OJK Regulation on Anti Money Laundering}

In response to the increasing risks relating to the provision of financial services and products, as well as to the recommendations made by the Financial Action Task Force on Money Laundering, the OJK has issued Regulation No. 12/POJK.01/2017 on the Implementation of Anti-Money-Laundering and Prevention-ofTerrorism-Financing Programs Within the Financial Sector (“AML PTF").

AML PTF is aiming to improve the implementation of antimoney-laundering and prevention-of-terrorism-financing programs through the implementation of a risk-based approach. To comply with the above AML PTF then the following information is necessary;

a) For natural persons, the following should be obtained by an insurance company: Legal name and any other names used, correct permanent address, telephone number, email address, date and place of birth, nationality, occupation or public position held and or name of employer, an official personal identification number, passport, identification card, driving license that bears a photograph of the consumer, type of policy and nature of insurance relationship, signature.

b) The insurance company should verify this information by at least one of the following methods; Confirming the date of birth from official documents, Confirming the permanent address, Contacting the consumer by telephone, by letter or by e-mail to confirm the information supplied after a policy account has been opened, Confirming the validity of the official documentation provided through certification by an authorized person. It is however, important to stress that this consumer acceptance policy will not be restrictive that it results in a denial of access by the general public to insurance services, especially for people who are financially or socially disadvantaged. These underlying principles of consumer identification for natural persons will have equal application to consumer identification for all products, branches and sales channels.
The purpose of the company requiring sufficient and appropriate information about consumers: This information is expected to be sufficient to provide an analysis of a consumer's personal and financial circumstances, leading to a clear identification of the consumer's need, so that a suitable investment can be recommended (as expected by OJK Regulation on Consumer Protection) ; Identify consumers business requirements from their profile; The company obtains consumer information when someone becomes a new consumer or applies for a new product or service to enable them to decide whether to accept the application; The company will use this information to help understand the profile of individual consumers or of its consumers as a whole, for marketing and product development purposes. In consummating the relationship, the following information will be required residential status, employment details, income, and other sources of income.

\section{Methods}

This study used qualitative methods that consist of a desk study of the literature and other relevant data that related to the implementation of consumer protection regulation, and also in-depth semistructured interviews with key informants from consumer protection related professionals in life insurance companies and regulators composed of 11 professionals who works in life insurance industry. The participants were comprised of 3 Head of Compliance, 2 Head of Consumer Services, 2 Head of Legal, 2 Head of Internal Audit and 2 Regulators. All participants were selected purposively to include employees from the 5 biggest life insurance companies in Indonesia and the regulator's staff who were directly involved in the consumer protection regulation formulation.

\subsection{Data Collection}

An in-depth semi-structured interview guide was used as the primary instrument of data collection. The validation process will be following up the interview results using the secondary data from regulator's statistics. The semi-structured instrument with both closed and open-ended questions were administered to selected participants who dealt with consumer protections related issues such as disputes settlement, misrepresentation cases, fraud cases, and complaints. Information validation, and probing issues were carried out in the field to verify the information.

\subsection{Interview Results}

Based on the interview conducted with the participants, there were three main issues raised on the existing implementation of the consumer protection regulation. The implementation issues were related to the effectiveness of the regulation, low supervision or lack of quality assurance from the regulator, and the clarity of the expectation from the regulator over specific life insurance key business processes or products such as claim process, telemarketing products, dispute handling and adequate disclosure in the onboarding process.

In addition, all participants concluded that life insurance industry will be benefiting from the implementation of the consumer protection. This view is also noted that there are potential risks raised from the low quality of consumer protection implementation.

The participants also raised the challenges they have in their roles such as quality and consistency for regulator, the need based selling for insurance companies, and the awareness and good communication for appointed dispute resolution body.

All these results will be further detailed in the next section of this paper. 


\section{Research Findings}

\subsection{The implementation of consumer protection in In- donesia life insurance industry is still a work-in pro- gress.}

Based on the in-depth interviews with three Head of Compliance, they opined that the implementation of consumer protection in the life insurance industry is still not running effectively and not as ideal as those set forth in the regulations related to consumer protection. For example, with regards to the requirements for life insurance companies to handle consumer complaints within 20 business days, many life insurance companies do not handle consumer complaints in accordance with the time required in practice. Even the regulators did not review the implementation of this requirement since the regulation was launched in 2013. The same issue is also verified by a statement from the Badan Mediasi Asuransi Indonesia (BMAI), one of the appointed external dispute resolution body, which stated that the consumer claims handler has not satisfied some of the policyholders. The misunderstanding between the insured and the policyholder over the obligation to disclose information and facts during the sale of the policy causes a dispute between the insurer and the policyholder (9).

The neutrality of the regulator is also highlighted by participants where there have been cases of fraudulent claims committed by organized crime syndicates using hospital income insurance products in the last two years. These cases have brought one Chief of Executive Officer (CEO) of a joint venture life insurance company and a Head of Claim to become suspects in relation with a police report filed by a consumer. The industry players reacted on this case and have made police reports as well as sought advice to regulators on responding to these frauds. They feel that the role of regulator is not balanced between supporting the life insurance companies and protecting the customers. The regulator is deemed as being indecisive in enforcing protection, including the protection of life insurance companies that became a victim in these cases. The CEO and the Head of Claim became suspects in accordance with the breaches of Consumer Protection Act (10). This shocking incident triggered the Government to revisit the Act and to revise it. Currently the revision of the Act is targeted to enter the National Legislation Program (PROLEGNAS) by 2019 and will be discussed with the House of Representatives in 2018 (11). From the consumer service point of view, several Head of Consumer Services pointed out that the Regulation should be more specific to the type of insurance product such as Unit Link Product and Tele-Marketing. The reason for these two products because these products are the main contributors of consumer complaints. For Unit Link Product, most of the consumers complained about the fund performance that was not in line with the so called "guaranteed or promised rate of return" during the sales process which reflected numbers of fraudulent selling cases in the industry where most of the consumers complained that they were being tricked by the tele-marketers who encouraged them to provide the consents during the recorded tele-marketing process. Although the Regulation is very clear on the matter of consumer consent for marketing the insurance product, the complaints on tele-marketing products still indicates that the consumer's data privacy of being contacted without proper consent is still a big question mark in life insurance industry. Both key points raised by the Head of Consumer Service are verified by the statistics that showed the insurance industry contributed to $24 \%$ of all consumer complaints in financial industry that were addressed to Regulator (12).

\subsection{Perceived benefits and risks from adequate imple- mentation of Consumer Protection in life insurance in- dustry.}

In general, the implementation of consumer protection is expected to align the position between the life insurance companies with consumers in order to create a healthy and mutually beneficial market conditions between the two parties. Particularly in the life insurance sector, consumer protection by the regulators provide many benefits to the community, including improving the transparency aspects of financial products and services. Through transparency supported by the availability and completeness of adequate information will encourage consumers and communities to better know the benefits, costs, and risks of insurance products and services before buying them. This transparency would provide a wide opportunity to select and compare the various products offered by insurance companies. In the other hand, for the life insurance companies themselves, consumer protection will provide benefits in growing business entities. Therefore, people feel more secure using products and services offered by life insurance companies so that loyalty and their numbers continue to increase. This is in line with the objective from regulator to improve the market penetration rate for life insurance products.

While for regulators as stated in an in-depth interview with the exregulator staff, the consumer protection efforts conducted by regulators are very useful for government and related institutions in creating the behavior of prudent financial services institutions and developing consumers and people who understand the products and financial services. Both benefits will result in a disciplined financial industry (market discipline) that will ultimately further expand access to finance. The condition will also support government programs in establishing a more financial secure community. There are potential risks when the aspects of consumer protection in the life insurance industry not implemented optimally. Based on the in-depth interviews with the participants, the current study identified five potential risks that will be faced by the insurance industry, as follows:

First, "no growth" of consumer protection culture both at the level of life insurance companies and the industry. This condition is a significant risk if associated with the efforts of the industry in building the market confidence. Without the right market confidence, the insurance industry will not grow well and sustainable. Second, the low level of supervision and governance of life insurance products and services offered to consumers and community. The risk of vulnerability that consumers face will increase when in product design, marketing, and in case of the dispute is not handled properly. The risk management aspect shall consider the risk of consumer protection implementation as an important part and not only seen it as a complement to the health of the insurance industry or companies.

Third, the increasing danger of consumer data security. Protection of personal data as a crucial factor in protecting the interests of consumers. It is important to have assurance for not misuse the consumer data, including data that requires consumer's consent if the life insurance company use it for product and service offerings purposes. This risk has been verified by the Indonesia Life Insurance Industry Association (AAJI) by officially inquired the explanation from the Tax Attorney General in relation with the recent requirement of newly issued regulation that requires insurance companies to share consumer's personal data to Tax Attorney General (13).

Fourth, the standard provisions of insurance agreement have not met the expected fairness. The standard provisions in the life insurance industry largely contain elements of raw clauses that should certainly not harm consumers, including transparency of benefits, costs and risks.

Finally, the lack of adequate complaints handling mechanism for consumers. Consumers need assurance of complaint handling and a clear governance if the complaint leads to a dispute. There should be a consistent implementation of dispute resolution as stated in the standard agreement between the two parties including if there is an alternative dispute settlement process using the appointed dispute resolution body. 


\subsection{Issues and Challenges in the implementation of Con- sumer Protection in life insurance industry.}

Based on the analysis, there are issues and challenges in the consumer protection implementation in life insurance industry in Indonesia. There are three levels of challenges based on the role namely: regulator, life insurance companies and the appointed dispute resolution body.

The main challenge on the part of the regulator is to show the seriousness and consistency in the implementation of consumer protection regulations. Regulators are required to send the right message to life insurance companies, consumers and relevant parties through the imposition of sanctions on "not complied" insurance companies, periodic assurance mechanisms for the implementation of this regulation and continuous efforts to raise awareness of consumers, life insurance companies and parties related to dispute resolution on the expectations of the implementation of consumer protection regulations. For instance, the Regulation expects the consumer to submit their complaints first to the insurance companies and then to use the appointed dispute resolution body if there was no agreement in place between the consumers and the insurance companies. The existing facts are the consumer prefers to submit the complaints directly to the police authority or to regulator without seeking mediation as agreed in the provisions stated in the life insurance policy. This was also happened to many cases including the fraud claims related to the organized crime syndicate which lead the CEO and the Head of Claim became suspects in the consumer report to the police. This challenge would require the regulators to build a comprehensive and continuous financial literacy program as part of its consumer protection initiatives.

For the life insurance companies, the main challenge would be how to implement the proper life insurance sales process by assessing the consumers' needs, their risk profile and using the consumer data properly. The challenge is referring to the fact that most of the consumer complaints were due to misrepresentation, misconduct by sales forces, and claim disputes due to lack of disclosure information submitted by the consumers during the application process. Considering that the life insurance industry would be heavily affected by the rapid growth of digital and financial technology, the life insurance industry must strengthen its need based selling process including the standard provisions, products features, exclusions, and the need of consumer consent shall be clearly explained to the potential consumers. The regulator in its official forecast of life insurance industry, predicts that the life insurance industry will have growth estimates range from $10 \%$ to $30 \%$ annually (14). The other challenge would be how to build an effective financial literacy and financial inclusion program to the consumers as required. The success and measurable programs would provide benefits to the life insurance companies in term of disputes reduction, small product mismatch and sustainable persistency rate.

On the other hand, there are many issues identified in the side of the appointed dispute resolution body. The challenges are the lack of awareness in the consumers on the role of the dispute resolution body, the lack of representatives of the dispute resolution body in various cities of Indonesia, lack of capability in handling dispute related to Unit Link Product and the lack of competence from the arbitrator or the mediator in the field of life insurance. The issues and the challenges in the dispute resolution body should be supported by the life insurance companies as well as regulator through the systematic awareness program on the role of the resolution body as well as the proper training to the arbitrator and mediator over the insurance product and its process. In addition, the appointed dispute resolution body needs to build a campaign over their existence by starting to establish representative office in the cities outside big cities in Indonesia. The clear communication with the police department also needs to be in place in case the unaware or uneducated consumers filed their complaints directly to the police authorities.

\section{Conclusion and Recommendation}

Consumer Protection is expected to align the position between the life insurance companies with consumers in order to create a healthy and mutually beneficial market conditions between the two parties. Nevertheless, the implementation of consumer protection in the life insurance industry is still a work in progress as it was not running effectively, inconsistent and not as ideal as those set forth in the regulations. There are several key benefits as well as key risks if the consumer protection is in place. There are numbers of issues such as inconsistency, lack of assurance on the quality of implementation, the improper selling process, the low awareness from the consumers, and the lack of capability and competence of the appointed dispute resolution body in dealing with life insurance product or process. To overcome these issues, this study suggests a number of actions: [1] Periodic regulator quality assurance for the quality of implementation in the form of assurance review and sanctions impose; [2] strengthening the need based selling for life insurance companies; [3] developing an effective and measurable financial literacy and financial inclusion programs for consumers; [4] building a life insurance product and process related competency and capability of the arbitrator and mediator from the appointed dispute resolution; and [5] establishing awareness and the existence of the dispute resolution body across cities in Indonesia.

\subsection{Implications for future research}

This study, being of an exploratory and interpretive nature, raises a number of opportunities for future research, both in terms of theory development and concept validation. More research will in fact be necessary to refine and further elaborate the above findings.

First, while this study has generated a useful insight of "customer experience" from the implementation of consumer protection regulation, very little can be said based on the 5 biggest life insurance companies' experience. This study could be extended in search of statistical, rather than analytical, generalizability, as we have sought here.

Second, this study offers the opportunity to refine and validate the concepts emerged from the inductive analysis. For example, the concept of providing transparency to the customers would encourage them to choose the best product that fits with their needs as well as to mitigate the dispute due to mis-selling risks. This concept will need further refinement and elaboration, in terms of both the customer's knowledge of life insurance products and the awareness of the customer's real needs of the insurance product. Finally, as discussed in the research findings, further work is necessary to examine the practices of the regulator's supervision in providing the reasonable assurance over the implementation of the regulation. Further research can thus shed light on the ideal quality assurance program, level of supervision or even the level of infrastructure required for each life insurance company to support the implementation of the consumer protection regulation.

\section{Conflict of Interest}

There is no conflict of interest.

\section{References}

[1] Otoritas Jasa Keuangan (2011). Undang undang no 21 tahun 2011 tentang Otoritas Jasa Keuangan. from http://www.ojk.go.id/id/regulasi/otoritas-jasa-keuangan/undangundang/Pages/undang-undang-nomor-21-tahun-2011-tentangotoritas-jasa-keuangan.aspx.

[2] Suryowati, Estu (2017). Rata-rata Belanja Asuransi Masyarakat Indonesia Capai Rp 1,29 Juta per Tahun, from http://ekonomi.kompas.com/read/2017/04/02/171500726/rata- 
rata.belanja.asuransi.masyarakat.indonesia.capai.rp.1.29.juta.per.tah n

[3] Otoritas Jasa Keuangan (2017). Peraturan No. 12/POJK.01/2017 tentang Penerapan Program Anti Pencucian Uang dan Pencegahan Pendanaan Terorisme di Sektor Jasa Keuangan. from http://www.ojk.go.id/id/regulasi/otoritas-jasakeuangan/peraturan-ojk/Pages/POJK-Nomor-12-POJK.01-2017.aspx.

[4] Kulsum, U. (2018). Aset IKNB capai Rp 2,064 triliun di Juli. Retrieved from https://keuangan.kontan.co.id/news/aset-iknb-capai-rp-2064triliun-di-juli.

[5] Investor Daily (2013). OJK perkuat perlindungan konsumen asuransi, from http://sp.beritasatu.com/ekonomidanbisnis/ojk-perkuatperlindungan-konsumen-asuransi/37942.

[6] Otoritas Jasa Keuangan (2013). Peraturan OJK No.1/POJK.07/2013 Tentang Perlindungan Konsumen Sektor Jasa Keuangan. from http://www.ojk.go.id/id/kanal/edukasi-danperlindungan-konsumen/regulasi/peraturan-ojk/Pages/POJK-

Perlindungan-Konsumen.aspx.

[7] The World Bank. (2009). Good Practices for Consumer Protection and Financial Literacy in Europe and Central Asia: A Diagnostic Tool [Ebook] (p. 9). Retrieved from HYPERLINK "http://siteresources.worldbank.org/INTECAREGTOPPRVSECDEV/R esources/GoodPractices_ConsumerProtection_Sep09.pdf" http://siteresources.worldbank.org/INTECAREGTOPPRVSECDEV/Re sources/GoodPractices_ConsumerProtection_Sep09.pdf

[8] Kitab Undang Undang Hukum Dagang (KUHD), article 251 Kementrian Hukum dan Perdagangan, from http://bppt.jabarprov.go.id/assets/data/arsip/KUHD_new_version.p df

[9] Mediatama, G. (2018). BMAI: Penanganan klaim asuransi belum memuaskan. Retrieved from https://keuangan.kontan.co.id/news/bmaipenanganan-klaim-asuransi-belum-memuaskan.

[10] R, M. (2018). Dirut Allianz Jadi Tersangka, Polisi: Asuransi Minta Rekam Medis. Retrieved from https://news.detik.com/berita/d3660117/dirut-allianz-jadi-tersangka-polisi-asuransi-minta-rekammedis.

[11] UU Perlindungan Konsumen Perlu Disempurnakan. (2018). Retrieved from: http://www.mediaindonesia.com/read/detail/120579uu-perlindungan-konsumen-perlu-disempurnakan.

[12] Mediatama, G. (2018). OJK: $24 \%$ pengaduan konsumen berasal dari asuransi. Retrieved from https://keuangan.kontan.co.id/news/ojk-24pengaduan-konsumen-berasal-dari-asuransi.

[13] Primadhyta, S. (2018). Industri Asuransi Minta Penjelasan Keterbukaan Data Nasabah. Retrieved from https://www.cnnindonesia.com/ekonomi/20170519110515-78215915/industri-asuransi-minta-penjelasan-keterbukaan-data-nasabah

[14] Hafiz, M. (2018). Seperti Apa Industri Asuransi pada 2018?. Retrieved from http://marketeers.com/seperti-apa-industri-asuransi-pada-2018/ 